\title{
INTERAKSI SOSIAL WANITA PENGRAJIN TENUN IKAT TROSO DALAM KEGIATAN PEMBERDAYAAN DAN KESEJAHTERAAN KELUARGA (PKK)
}

\author{
Himmah Wafiroh \\ Mahasiswa Pascasarjana UNDIP Semarang, \\ Jawa Tengah Indonesia \\ himmahwafiroh@gmail.com
}

\begin{abstract}
Most of the workers of the home industry of handicraft weaving (Tenun) are housewives. Their husbands work as farmers or farm laborers. Most of the workers weaving craftsmen (Tenun) more occupied by women because weaving requires precision, tenacity, and high perseverance. It is kind of stigma of a woman who is able to do more than man.

The problem of working women is that they are less able to divide their time besides doing handicraft weaving and completing the household chores such as cooking, sweeping, taking care of the house and raising the child. However, as a worker and a housewife as well did not make them forget how to socialize in the society. Social activities that women workers of weaving handicraft (Tenun) such as PKK.
\end{abstract}

Keywords: Social interaction, waving handicraft (tenun), PKK

Abstrak : para pekerja usaha indutri rumah kerajinan tenun adalah
para ibu rumah tangga. Kebanyakan suami mereka bekerja sebagai
petani atau buruh petani. kebanyakan para pekerja pengrajin Tenun
lebih ditekuni oleh wanita karena menenun membutuhkan
ketelitian, keuletan, dan ketekunan yang tinggi. itu merupakan
stigma wanita yang memang cocok melakukan pekerjaan itu.
Permasalahan yang terjadi para wanita pekerja adalah kurang bisa
membagi waktu disamping harus membuat tenun setiap hari, juga
harus menyelesaikan pekerjaan-pekerjaan rumah tangga memasak,
menyapu, merawat rumah dan mengasuh anak, dll. Meski demikian,
wanita pengrajin Tenun Ikat Troso mampu membagi waktunya 


\section{INTERAKSI SOSIAL WANITA PENGRAJIN TENUN...}

dengan tidak melupakan kewajibannya sebagai makhluk sosial. Dimana setiap manusia harus bersosialisasi dengan manusia lain. Kegiatan sosial untuk wanita di Desa Troso ini salah satunya adalah kegiatan PKK.

Kata Kunci: interaksi sosial, wanita pengrajin Tenun Troso, PKK

\section{A. PENDAHULUAN}

Manusia ialah makhluk yang berhadapan dengan diri pribadinya dan dengan lingkungan sekitarnya. Antara manusia dengan lingkungan sekitar terdapat relasi timbal balik yang sangat erat. Pada relasi timbal balik ini menentukan dan ditentukan hakikat kemanusiaan.Jadi dapat dikatakan bahwa pribadi manusia hanya dapat berkembang apabila berada di dalam kelompok sosial. Sebagai makhluk sosial manusia selalu mengadakan interaksi dengan manusia lain untuk melakukan aktivitas-aktivitas dalam kehidupannya. Interaksi sosial adalah proses dimana antara individu dengan individu, individu dengan kelompok atau kelompok dengan kelompok berhubungan satu dengan yang lain.

Interaksi sosial merupakan kunci dari semua kehidupan sosial, tanpa interaksi sosial tidak akan mungkin ada kehidupan. Bertemunya manusia dengan manusia lain tidak akan menghasilkan pergaulan tanpa adanya interaksi sosial. Dan terjadinya interaksi sosial akan menghasilkan aktivitas sosial. Pada dasarnya interaksi sosial merupakan syarat utama terjadinya aktifitas sosial.

Salah satu sifat manusia adalah keinginan untuk hidup bersama dengan manusia lainnya.Dalam hidup bersama antara manusia dengan manusia atau manusia dengan kelompok terjadi hubungan dalam rangka memenuhi kebutuhan hidupnya.Melalui hubungan itu manusia ingin menyampaikan maksud, tujuan dan keinginan masing-masing.Sedangkan untuk mencapai keinginan itu harus diwujudkan dengan tindakan melalui hubungan timbal-balik (Basrowi, 2005: 138).

Proses interaksi terjadi dalam kehidupan bermasyarakat. Masyarakat merupakan sekumpulan manusia yang secara relatif mandiri hidup bersama-sama dalam waktu yang cukup lama yang 
mendiami suatu wilayah tertentu, memiliki kebudayaan yang sama dan melakukan sebagian besar kegiatan dalam kelompok tersebut.

Menurut Prayitno dan E. Amti, sebagai makhluk monodualis manusia terdiri dari unsur jasmani dan rohani yang merupakan kesatuan yang utuh. Dalam pertumbuhan, perkembangan dan kehidupan manusia mempunyai kebutuhan.Kebutuhan-kebutuhan itu untuk dapat diperhatikan dalam upaya mencapai kesejahteraan dan kebahagiaan hidupnya. Untuk memenuhi kebutuhan hidup dan kesejahteraan, individu harus bekerja dengan cara sesuai norma yang berlaku dalam masyarakat antara lain bertani, berdagang, buruh bangunan, polisi, guru, pegawai swasta dan buruh pabrik. Pekerja/buruh adalah setiap orang yang bekerja dengan menerima upah atau imbalan dalam bentuk lain. Buruh wanita adalah tenaga kerja wanita yang bekerja pada pengusaha/perusahaan dengan menerima upah. Dalam Kartini Kartono, mendefinisikan tentang wanita karier sebagai berikut: "Wanita yang sedang memasuki angkatan kerja (mencari/memilih) atau yang sudah menjadi angkatan kerja, baik sebagai buruh, kerja sendiri maupun berwiraswasta" (Siswanto, 2012: 24).

Menurut Heni Widyastuti pada umumnya wanita karier memiliki masalah intern, seperti terbatasnya waktu dan kesempatan mendidik anak, tugas rumah tangga yang terbengkalai, lemahnya kondisi fisik akibat kerja di kantor. Sedangkan masalah ekstern yang dihadapi antara lain kurangnya pengertian suami terhadap keadaan istri, sulitnya berperan ganda karena sebagian besar suami menyerahkan pekerjaan rumah tangga dan pendidikan anak kepada istri, faktor pandangan lingkungan yang kadang-kadang tidak mengenakkan hati (Kartono, 2006: 72).

Begitu halnya dengan tenaga kerja wanita atau biasa disebut pengrajin yang bekerja di perusahaan tenun ikat Troso yang menjual jasa dari tenaganya.Troso adalah nama salah satu desa yang terdapat di kecamatan Pecangaan KabupatenJepara. Di desa inilah tempat komunitas pengrajin tenun ikat troso berada.Desa Troso Kecamatan Pecangaan Kabupaten Jepara adalah sentra kerajinan kain tenun Troso yang merupakan produk unggulan Kabupaten Jepara setelahindustri mebel dan pariwisatanya.Desa ini terletak sekitar 15 $\mathrm{Km}$ arah Tenggara Kota Jepara.Kain tenun troso Jepara ini diproduksi 


\section{INTERAKSI SOSIAL WANITA PENGRAJIN TENUN...}

oleh masyrakat sekitar sendiri tanpa alat bantu mesin.Motif khas yang bernuansa etnis, tradisional, klasik, dan unik pun masih dipertahankan padakain tenun troso disamping motif kontemporer modern.

Pengrajin kain tenun torso didominasi oleh kaum wanita.Peran seorang wanita bukan hanya dilihat dalam kinerjanya dalam bekerja, tetapi wanita mempunyai andil besar dalam membentuk sebuah keluarga yang bermartabat.Lebih dari itu, wanita juga mempunyai andil besar dalam kegiatan penanggulangan kemiskinan melalui pemberdayaan masyarakat dan kelompok.Salah satu bukti, bahwa wanita mampu meningkatkan kesejahteraan keluarga dengan melakukan kegiatan usaha produktif rumah tangga.Dengan salah satu wadah organisasi wanita dimasyarakat Desa dan Kelurahan yaitu Pemberdayaan dan Kesejahteraan Keluarga atau biasa disebut PKK.

Kondisi sebagai ibu rumah tangga dan pengrajin tenun ikat Troso tidak membuat para wanita tersebut melupakan kewajibannya sebagai makhluk sosial. Dimana setiap manusia harus bersosialisasi dengan manusia lain. Kegiatan sosial untuk wanita di Desa Troso ini salah satunya adalah kegiatan PKK. Hal ini menarik untuk dibahas bagaimana para wanita pengrajin tenun ikat ini masih bisa meluangkan waktunya untuk mengurus rumah tangga dan masih bisa bersosialisasi dengan tetangga dan kegiatan di masyarakat khususnya PKK.

\section{B. PEMBAHASAN}

\section{Pengertian Interaksi Sosial}

Pengertian tentang interaksi sosial sangat berguna di dalam memperhatikan dan mempelajari berbagai masalah masyarakat.Menurut Bonner dalam Gunawan interaksi sosial adalah suatu hubungan antara dua orang atau lebih, sehingga kelakuan individu yang satu mempengaruhi, mengubah, atau memperbaiki kelakuan individu yang lain, dan sebaliknya (Adi Saputro, 2000: 31).

Menurut Kimball Young dan Raymond W. Mack dalam Soekanto ,interaksi sosial adalah kunci dari semua kehidupan sosial, oleh karena tanpa interaksi sosial tidak akan mungkin ada kehidupan bersama. Dalam kehidupan bersama setiap individu dengan individu 
lainnya harus mengadakan komunikasi yang merupakan alat utama bagi sesama individu untuk salingkenal dan bekerja sama serta mengadakan kontak fisik dan non fisik secara langsung maupun tidak langsung (Soekanto, 2000: 67).

Dalam bukunya Sosiologi suatu pengantar, Soekanto ,mengutip defenisi Gillin dan Gillin, yaitu interaksi sosial merupakan hubungan sosial yang dinamis, menyangkut hubungan antara individu, antara kelompok, maupun antara individu dengan kelompok(Soekanto, 2000: 67). Menurut Soekanto suatu interaksi sosial tidak akan mungkin terjadi apabila tidak memenuhi dua syarat, yaitu:

a. Kontak Langsung

b. Komunikasi(Soekanto, 2000: 71).

Kontak merupakan aksi dari individu atau kelompok yang mempunyai maknabagi pelakunya dan kemudian ditangkap oleh invidu atau kelompok lain. Makna yang diterima direspon untuk memberikan reaksi.Kontak dapat terjadi secara langsung maupun tidak langsung.Secara langsung melalui gerak dari fisikal organisme, misalnya melalui pembicaraan, gerak dan isyarat.Sedangkan kontak tidak langsung adalah lewat tulisan atau bentuk-bentuk komunikasi jarak jauh seperti telepon, chatting, dan sebagainya.Setelah terjadi kontak langsung muncul komunikasi. Terjadinya kontak belum berarti telah ada komunikasi, oleh karena komunikasi itu timbul apabila seorang individu memberikan tafsiran pada perilaku orang lain. Dalam tafsiran itu lalu seseorang mewujudkan perilaku dimana perilaku tersebut merupakan reaksi terhadap perasaan yang ingin disampaikan oleh orang lain.

Interaksi pada dasarnya merupakan siklus perkembangan dari struktur sosial yang merupakan aspek dinamis dalam kehidupan sosial. Perkembangan inilah yang merupakan dinamika yang tumbuh dari pola-pola perilaku individu yang berbeda menurut situasi dan kepentingan masing-masing yang diwujudkan dalam proses hubungan sosial. Hubungan-hubungan sosial itu pada awalnya merupakan proses penyesuaian nilai dalam kehidupan sosial. Kemudian meningkat menjadi semacam pergaulan yang ditandai adanya saling mengerti tentang maksud dan tujuan masing-masing pihak.Sudah menjadi hukum alam dalam kehidupan individu bahwa 


\section{INTERAKSI SOSIAL WANITA PENGRAJIN TENUN...}

keberadaan dirinya adalah sebagai makhluk individu dan makhluk sosial.

Adapun ciri-ciri dari interaksi sosial adalah:

a. Jumlah pelakunya lebih dari seorang, biasanya dua atau lebih.

b. Adanya komunikasi antar pelaku dengan menggunakan simbolsimbol.

c. Adanya suatu dimensi waktu yang meliputi masa lampau, kini, dan akan datang, yang menentukan sifat dari aksi yang sedang berlangsung.

d. Adanya suatu tujuan tertentu.

Berdasarkan pendapat beberapa tokoh diatas dapat disimpulkan bahwa, interaksi sosial adalah suatu proses hubungan sosial yang dinamis baik dilakukan oleh perorangan maupun kelompok manusia sehingga terjadi hubungan yang timbal balik antara individu atau kelompok yang satu dengan yang lain untuk mencapai tujuan masing-masing dalam rangka memenuhi kebutuhan hidup. Interaksi sosial merupakan hubungan yang tertera dalam bentuk tindakan-tindakan yang berdasarkan nilai-nilai dan normanorma sosial yang berlaku dalam masyarakat. Bila interaksi itu berdasarkan pada tindakan yang sesuai dengan nilai dan norma yang berlaku, maka hubungan tersebut akan berjalan dengan lancar.

Interaksi adalah hubungan timbal balik antara dua orang atau lebih, dan masing-masing orang yang terlibat didalamnya memainkan peran secara aktif.Interaksi sosial yang dimaksud dalam penelitian ini adalah hubungan sosial wanita pengrajin tenun ikat troso dengan lingkungan tempat tinggalnya khususnya dalam kegiatan PKK.

\section{Definisi Kerajinan tenun ikat Troso}

Indonesia dikenal begitu banyaknya kerajinan yang tersebar dan terus berkembang.Kerajinan tercipta karena sifat dasar yang dimiliki oleh manusia.Hal ini dikarenakan manusia memiliki tangan terampil untuk menciptakan dan menghasilkan suatu barang atau benda kerajinan yang memiliki nilai keindahan.

Definisi kerajinan menurut Wiyadi yaitu kerajinan adalah semua kegiatan dalam bidang industri atau pembuatan barang sepenuhnya dikerjakan oleh sifat rajin, terampil, ulet sertakreatif 
dalam upaya pencapaianya (Wiyadi, 1991: 915). Menurut Sumintarsih dijelaskanbahwa:Kerajinan adalah budaya bangsa yang telah ada sejak zaman nenekmonyang, pada mulanya kerajinan timbul karena adanya doronganmanusia untuk mempertahankan hidupnya, keludian lama-kelamaanmanusia membuat alat-alat kebutuhan sehari-hari seperti alat pertanian,alat untuk berburu dan berperang, peralatan rumah tangga, dan peralatanmengolah untuk mengolah makanan. Pada kegiatan kerajinan itu timbulatas desakan kebutuhan praktis dengan menggunakan bahan yang ada danpengalaman kerja yang diperoleh dari kehidupan seharihari.Sehinggahasil kerajinan itu masih yang sangat dipengaruhi oleh lingkungan danmanusia pendukungnya. Kerajinan tersebut membutuhkan modalketelitian, keuletan, ketekunan, dan mengandalkan ketrampilan tangan (Isyanti, tth: 17).

Pengrajin ialah orang yang pekerjaannya membuat barangbarang kerajinan atau orang yang mempunyai keterampilan berkaitan dengan kerajinan tertentu, seperti kelompok penenun ikat Troso dapat disebut pengrajin tenun ikat Troso dari jepara .Barangbarang tersebut tidak dibuat dengan mesin, tetapi dengan tangan sehingga sering disebut barang kerajinan tangan (http://rubrikbahasa.wordpress.com/2011/06/15/).

Sedangkan pengertian dalam Kamus Besar Bahasa Indonesia, Kerajinan adalah sifat yang sebagainya rajin, membuat sesuatu, atau kerajinan merupakan usaha yang dilakukan para pengrajin dalam menghasilkan barang hasil karya yang bernilai seni (KBBI, 2003: 399). Kain adalah barang tenunan yang dipakai untuk pakaian dan sebagainya atau untuk maksud lain. Kain tenun adalah barang tenun atau barang yang dibuat dari benang, kapas, sutera dan sebagainya(KBBI, 2003: 230, 529).Tenun merupakan salah satu elemen mode khas Indonesia selain batik.Kekayaan tekstil khas Indonesia ini merupakan hasil kerajinan yang dibuat dari hasil tenunan bersulam benang emas atau perak, dan dengan kombinasi benang berwarna lainnya (http://forum.vivanews.com, diakses 4 Desember 2017).

Berdasarkan pengertian tersebut, kerajinan kain tenun adalah usaha yang dilakukan para pengrajin dalam menghasilkan barang hasil karya yang bernilai seni, yang dibuat dari hasil tenunan 


\section{INTERAKSI SOSIAL WANITA PENGRAJIN TENUN...}

bersulam benang emas atau perak, dan dengan kombinasi benang berwarna lainnya.

Hasil kerajinan yang dihasilkan masyarakat Kota Jepara yang berada di Jawa tengah, pada mulanya bersumber kepercayaan turun temurun dan menjadi tradisi yang tidak bisa ditinggalkan. Hal ini sudah mendarah daging dan menjadi bagian kehidupan masyarakat Kota Jepara, banyak seni kerajinan di Jepara salah satunya yang terkenal sampai mancanegara adalah kerajinan ukirnya, di kota Jepara terdapat salah satu kerajinan tekstil yaitu kerajinan tenun ikat.

Troso. Di kota kecil inilah terdapat sebuah desa yang menjadi pusat produksi kain-kain tradisional yaitu kain ikat atau tenun Troso, demikian kain-kain tersebut dikenal. Pada masyarakat di Desa Troso pembuatan suatu barang kerajinan sudah menjadi suatu hal yang dilakukan karena berkaitan dengan kebutuhan baik lahiriah maupun kebutuhan spritual.Kerajinan tenun merupakan salah satu hasil budidaya masyarakat Desa Troso dalam memenuhi kebutuhan.

Proses pembuatan kain tenun, sebagai sarana pemenuhan bahan sandang telah dikenal dan diterapkan diseluruh belahan dunia. Walaupun proses pembuatan kain tenun telah dikenal di setiap negara di dunia, akan tetapi teknik pembuatannya beraneka ragam. Keaneragaman teknik pembuatan kain tersebut disebebkan oleh perbedaan Sumberdaya alam pada lingkungan tempat para penenun tinggal.

Di Indonesia, terdapat beberapa teknik pembuatan kain tenun yang berbeda namun umumnya menggunakan alat tenunan yang sama. Alat tenun tersebut berupa rangkaian bilah bambu yang diikat dengan menggunakan tali. Menurut Salamun dkk, jenis tenun berdasarkan teknik pembuatannya ada tiga macam yaitu tenun ikat, tenun buna, dan tenun lotis. Tenun ikat merupakan proses pembuatan kain yang motifnya dibuat pada benang pakan, lungsi, maupun keduabenang tersebut dengan cara diikat dengan menggunkan tali pengikat yang dapat melindungi motif dari zat warna. Umumnya, proses pembuatan tenun ikat pakanmaupun mengunakan pola anyaman polos karena motif telah dibuat sebelumnyapada benang pakan maupun lungsinya (Salamun, 2013: 47). 
Menurut Kamus Besar Bahasa Indonesia, tenun merupakan hasil kerajinan yang berupa bahan atau kain yang dibuat dari benang (kapas, serat, sutera) dengan menggunakan pakan secara melintang pada lungsi (KBBI, 1988: 104).Penjelasan ini di pertegas dalam Ensiklopedia Nasional Indonesia yaitu:Tenun adalah bahan kerajinan berupa bahan kain yang dibuat dari benang serat, kapas, sutera. Dengan cara memasukkan pakan secara melintang pada lungsi dua kelompok benang yang membujur disebut lungsi, sedangkan benang yang melintang disebut pakan (Ensikloedia Nasional Indonesia, 1991: 242).

Dalam Budiyono (2008: 421), mengungkapkan bahwa Tenun merupakan teknik dalam pembuatan kain yang dibuat dengan azaz (prinsip) yang sederhana yaitu dengan menggabungkan benang secara memanjang dan melintang.

Dari pendapat di atas mengenai tenun, dapat disimpulkan bahwatenun merupakan proses pembuatan kain yang melibatkan dua jenis benang yaitubenang lungsi dan benang pakan, yang saling menyilang dengan membentuk polaanyaman tertentu. Pada alat tenun, benang lungsi dipasang memanjang antaraboom tenun sampai penggulung kain dengan melewati kedua gun dan suri danbenang pakannya dipasang melebar.

Alat yang digunakan untuk menenun kain secara umum adalah gedokan dan ATBM (Alat Tenun Bukan Mesin). (1) Alat yang masih sangat tradisional adalah gedokan yang difungsikan secara tradisional. Penggunaan alat gedokan ini dalam membuat kain akan menghasilkan kain dengan lebar $55 \mathrm{~cm}$, sehingga untuk membuat kain sarung dengan panjang $110 \mathrm{~cm}$ dengan panjang dua meter dibutuhkan lebih banyak bahan dan waktu penyelesaian satu buah kain sarung adalah $3-4$ bulan. (2) ATBM (Alat Tenun Bukan Mesin) dengan menggunakan alat ini, dalam satu hari bisa dihasilkan 3 -5 meter kain dengan lebar 70, 90, dan $110 \mathrm{~cm}$.

Tenun menenun merupakan tradisi yang diwariskan secara turun temurun, dan dilakukan oleh hampir seluruh kaum wanita pada usia tertentu. Tenun, sebagai proses pembuatan kain yang cukup tua di Indonesia berkembang pesat dan memiliki tempat tersendiri di hati masyarakat luas. Keberadaannya tak hanya sebagai bahan sandang semata, akan tetapi memiliki sejarah panjang dan 


\section{INTERAKSI SOSIAL WANITA PENGRAJIN TENUN...}

kebanyakan menceritakan tentang budaya suatu daerah dikarenakan masyarakat Indonesia cenderung menggunakan gambar sebagai media untuk menceritakan sejarah

\section{Sekilas tentang wanita pengrajin tenun ikat Troso}

Wilayah Indonesia banyak ditemui sentra pengrajin tenun Ikat.Setiap daerah juga mempunyai keunikan dan kekhasan tersendiri, baik dalam ragam hias maupun tata warnanya.Salah satu daerah itu adalah Desa Troso kecamatan Pecangaan Kabupaten Jepara. Desa tersebut banyak terdapat pengrajin Tenun Ikat yang sangat potensial. Desa Troso merupakan kampung Tenun Ikat yang diproduksi oleh para pengrajin di Desa Troso jika dicermati di dalamnya mengandung nilai-nilai yang pada gilirannya dapat dijadikan sebagai acuan dalam kehidupan sehari-hari bagi masyarakat pecinta pecinta Tenun Ikat. Nilai-nilai itu antara lain, kesakralan, keindahan/seni, ketekunan, ketelitian dan kesabaran. Nilai keindahan tercermin dari motif ragam hiasnya yang dibuat sedemikian rupa sehingga memancarkan keindahan, sedangkan nilai ketekunan, ketelitian dan kesabaran tercermin dari proses pembuatannya yang cukup menyita waktu yang panjang dan lama untuk menghasilkan sebuah Tenun Ikat yang bagus, menarik, dan disukai oleh banyak orang.

Tenaga kerja pada usaha home industry kerajinan Tenun Ikat adalah tenaga wanita berasal dari anggota rumah tangga sendiri dan sebagian lagi mengupah pekerja dari tetangga di dekat rumah. Suami mereka bekerja sebagai petani atau pekerjaan lain diluar pertanian. Pekerjaan menjadi pengrajin Tenun lebih banyak ditekuni oleh wanita karena menenun memerlukan ketelitian, keuletan, dan ketekunan yang tinggi, dan wanita yang memang cocok melakukan pekerjaan itu.Tenaga kerja laki-laki biasanya hanya membantu saja terutama dalam hal pemasaran.Kegiatan home industry kerajinan Tenun Ikat memerlukan keahlian khusus, sehingga tidak mudah bagi setiap orang untuk terjun ke dalam usaha tersebut.Home industrykerajinan Tenun Ikat di desa Desa Troso merupakan kerajinan yang diwariskan secara turun temurun diperoleh dari orang tua, sehingga pada umumnya home industry kerajinan Tenun Ikat masih dikerjakan untuk meneruskan usaha orang tua. 


\section{Interaksi sosial wanita pengrajin tenun dengan PKK}

Pemberdayaan dan Kesejahteraan Keluarga atau PKK merupakan wadah untuk membina keluarga bermasyarakat baik di perkotaan maupun di pedesaan yang dapat menghasilkan sinergi untuk keluarga sejahtera yang mandiri dengan meningkatkan mental spiritual perilaku hidup dengan menghayati dan mengamalkan Pancasila. Dapat dikembangkan lebih luas lagi dengan berbagai upaya atau usaha dan kegiatan, seperti meningkatkan pendidikan dan ketrampilan yang diperlukan, ikut mengupayakan dalam kehidupan bangsa serta meningkatkan pendapatan keluarga, meningkatkan kualitas adan kuantitas pangan keluarga, meningkatkan derajat kesehatan, kelestarian lingkungan hidup serta membiasakan hidup berencana dalam semua aspek kehidupan dan perencanaan ekonomi keluarga dengan membiasakan menabung.

Dalam melakukan kegiatan tersebut perlu adanya pengelolaan PKK baik kegiatan pengorganisasian maupun pelaksaan program-program, yang disesuaikan dengan situasi dan kondisi masyarakat (Oetomo, 2006: 3).Dengan adanya kegiatan PKK diharapkan dapat meningkatkan kesetaraan keluarga pada umumnya yang berpedoman pada pelaksaan kegiatan 10 Program Pokok PKK.Selain memiliki program-program pokok, PKK juga memiliki panca dharma PKK. Isi dari panca dharma ini tentang perananperanan wanita dalam kehidupan, yaitu sebagai berikut:

a. Wanita sebagai pendamping suami

b. Wanita sebagai pengelola rumah tangga

c. Wanita sebagai penerus keturunan dan pendidik anak

d. Wanita sebagai pencari nafkah tambahan

e. Wanita sebagai warga negara dan anggota masyarakat

Wanita pengrajin tenun yaitu untuk menjadi seorang wanita pengrajin tenun tidaklah mudah, mengingat jam kerja yang tidak bisa diperkirakan dan waktu berkumpul dengan keluarga serta waktu bersosialsisasi dengan lingkungan terbatas. Namun sebagai anggota masyarakat wanita pengrajin tenun juga mempunyai kewajiban untuk bersosialisasi dan mengikuti segala kegiatan yang ada di Desa Troso Salah satu organisasi untuk wanita yaitu PKK, apabila wanita pengrajin tenun bisa membagi waktunya antara keluarga dan 


\section{INTERAKSI SOSIAL WANITA PENGRAJIN TENUN...}

lingkungan masyarakat maka dengan mengikuti kegiatan PKK akan menimbulkan interaksi sosial. Interaksi sosial yang terjadi akan mengacu pada Panca Dharma Wanita, yang isinya adalah wanita sebagai pendamping suami, wanita sebagai pengelola rumah tangga, wanita sebagai penerus keturunan dan pendidik anak, wanita sebagai pencari nafkah tambahan, serta wanita sebagai warga negara dan anggota masyarakat.

\section{Proses Interaksi Sosial Wanita Pengrajin Tenun Dengan PKK}

Tingkah laku manusia sebagai makhluk individu berbeda dengan tingkah laku manusia sebagai makhluk sosial.Tingkah laku manusia sebagai makhluk sosial sangat dipengaruhi oleh lingkungan sosialnya.Manusia tidak dapat dilepaskan dari kehidupan sosialnya, di mana mereka harus bergaul dengan sesama.Interaksi sosial merupakan hubungan-hubungan sosial yang dinamis yang menyangkut hubungan antara orang-orang perorangan, antara kelompok-kelompok manusia, maupun antara orang perorangan, antara kelompok-kelompok manusia.Interaksi sosial adalah kunci semua kehidupan sosial, oleh karena itu tanpa adanya interaksi sosial, tidak akan mungkin ada kehidupan bersama9Soekanto, tth: $55)$.

Hubungan interaksi sosial antara wanita pengrajin tenundengan masyarakat Desa Troso berjalan baik dan tidak pernah terjadi perselisihan. Mereka saling mengadakan kontak sosial dan berkomunikasi satu dengan yang lain. Kontak sosial yang dilakukan secara langsung maupun tidak langsung diwujudkan dalam kegiatankegiatan PKK di Desa.Melalui kegiatan PKK ini wanita pengrajin tenundapat mudah untuk berkomunikasi dengan warga sekitar.

Dalam interaksi sosial terdapat beberapa bentuk-bentuk sosial yaitu berupa kerja sama, persaingan, pertentangan dan akomodasi. Basrowi mengatakan "keempat bentuk pokok interaksi sosial tidak merupakan suatu kesinambungan", artinya bahwa interaksi itu tidak hanya dimulai dari kerja sama, kemudian menjadi persaingan dan akomodasi, serta akhirnya memuncak menjadi pertikaian. Akan tetapi, hal itu tergantung pada situasi dan kondisi tertentu, serta bisa diawali dengan persaingan.Setelah itu, akomodasi atau sebaliknya (Basrowi, 2005: 145). 
Dalam tulisan ini interaksi sosial yang terjadi pada wanita pengrajin tenundi Desa Troso adalah adanya hubungan kerja sama antara keluarga dan masyarakat dalam kegiatan PKK. Dengan menjalin hubungan dan kerja sama yang baik inilah sehingga tidak ada persaingan maupun pertentangan dalam proses interkasinya. Dan akomodasi yang terjadi yaitu menunjuk pada suatu keadaan yang berarti kenyataan adanya suatu keseimbangan dalam interaksi antara wanita pengrajin tenundan warga yang berhubungan dengan norma dan nilai sosial yang berlaku di masyarakat.

Para wanita pengrajin tenundi Desa Troso berusaha keras untuk mewujudkan peranan-peranannya sebagai seorang wanita dan tidak lupa melaksanakan kewajibannya.Kebanyakan mereka bekerja untuk membantu memenuhi kebutuhan keluarganya dan ada pula sebagai tulang punggung keluarga karena berstatus janda.Dengan waktu yang terbatas, mereka berupaya untuk bisa menjadi seorang istri, ibu dan anggota masyarakat yang baik.Sebelum berangkat kerja mereka menyiapkan makanan untuk suami dan anaknya, mereka juga menyiapkan perlengkapan sekolah anak-anaknya.Apabila ada kegiatan yang diadakan di Perumahan mereka juga berusaha agar bisa mnegikuti semua kegiatan-kegiatan tersebut khususnya kegiatan PKK.

Terdapat keunikan dari wanita pengrajin tenun ini, yaitu menurut Heni Widyastuti, pada umumnya wanita karier memiliki masalah intern, seperti terbatasnya waktu dan kesempatan mendidik anak, tugas rumah tangga yang terbengkalai, lemahnya kondisi fisik akibat kerja di kantor. Sedangkan masalah ekstern yang dihadapi antara lain kurangnya pengertian suami terhadap keadaan istri, sulitnya berperan ganda karena sebagian besar suami menyerahkan pekerjaan rumah tangga dan pendidikan anak kepada istri, faktor pandangan lingkungan yang kadang-kadang tidak mengenakkan hati (Kartono, 2006: 72).

Permasalahan yang terjadi pada wanita Desa Troso yang membuat Tenun Ikat, wanita yang memang secara turun temurun mewarisi bakat membatik tersebut setiap harinya memproduksi Tenun Ikat secara manual dan penuh dengan ketekunan. Akibatnya mereka kurang bisa membagi waktu disamping harus membuat tenun setiap hari, juga harus menyelesaikan pekerjaan-pekerjaan 


\section{INTERAKSI SOSIAL WANITA PENGRAJIN TENUN...}

rumah tangga mulai memasak, menyapu, merawat rumah dan mengasuh anak, maka berdasarkan latar belakang diatas, penulis tertarik untuk meneliti upaya wanita dalam meningkatkan ekonomi keluarga melalui home industry Tenun Ikat di Desa Desa Troso, Kecamatan Pecangaan Kabupaten Jepara.

\section{Faktor Pendorong dan Penghambat Interaksi Sosial Wanita Pengrajin tenun dalam Kegiatan PKK}

Interaksi Sosial Wanita Pengrajin tenundalam Kegiatan PKK mempunyai beberapa faktor pendorong dan penghambat. Faktorfaktor tersebut antara lain:

a. Faktor Pendorong

Wanita mempunyai beberapa peranan penting dalam kehidupan yaitu wanita sebagai pendamping suami, wanita sebagai penerus keturunan, wanita sebagai pengasuh anak, wanita sebagai pencari nafkah tambahan dan wanita sebagai warga Negara dan anggota masyarakat.Agar peranan tersebut bisa berjalan dengan baik perlu adanya dorongan dari dalam dan luar.Dari dalam yaitu diri sendiri dan dari luar yaitu keluarga dan masyarakat. Dengan adanya kesadaran dari diri sendiri akan pentingnya berinteraksi dengan sesama, maka wanita pengrajin tenunini dapat menyisihkan waktunya untuk mengikuti kegiatan di masyarakat khususnya kegiatan PKK. Selain kesadaran, waktu yang sangat terbatas juga menjadi salah satu pendorong wanita pengrajin tenununtuk mewujudkan peran-perannya sebagai wanita. Dorongan dari luar yaitu keluarga dan masyarakat yang terwujud dalam pengertian dan hubungan kerja sama. Keluarga adalah faktor utama sebagai pendorong bagi wanita pengrajin tenununtuk terus semangat menjalankan profesinya sebagai pekerja dan anggota masyarakat khususnya anggota PKK.

\section{b. Faktor Penghambat}

Menjadi wanita pengrajin tenuntidaklah mudah, karena memiliki jam kerja yang tidak menentu.Mereka harus pandai membagi waktu untuk pekerjaan, keluarga dan masyarakat. Upaya ini merupakan cara wanita pengrajin tenununtuk berinteraksi dengan sesama. Inilah kendala utama menjadi wanita pekerja pabrik, 
yaitu jam kerja yang tidak menentu dan keterbatasan waktu yang dimiliki. Faktor penghambat yang lain yaitu masalah ekonomi, banyak diantara mereka yang bekerja menjadi pengrajin tenununtuk membantu perekonomian keluarga. Ada pula yang menjadi tulang punggung keluarga.Tetapi hambatan yang timbul dari keluarga ini juga dapat dijadikan sebagai penyemangat mereka.

Berdasarkan uraian interaksi sosial wanita pengrajin tenundiatas dapat diketahui bahwa para mereka berusaha membagi waktunya agar dapat berinteraksi dan menjalin hubungan yang baik dengan keluarga dan masyarakat. Walaupun kadang-kadang ada subjek yang masih pasif mengikuti kegiatan PKK dan memilih-milih kegiatan yang akan diikuti karena kecapekan bekerja, tetapi subjek tetap masih berusaha meluangkan waktu untuk mengikuti kegiatan PKK tersebut. Dan menyadari bahwa melalui kegiatan PKK inilah, subjek dapat berinteraksi dengan baik.

Adapun kendala waktu terbatas yang ada selama ini dapat pula dijadikan sebagai pendorong mereka.Sedangkan kendala dari pihak keluargapun juga bisa dijadikan faktor pendukungnya yaitu keluarga sebagai penyemangat bekerja dan agar tercapainya kehidupan yang lebih baik.

\section{KESIMPULAN}

Proses interaksi sosial wanita pengrajin Tenun dalam kegiatan PKK di Desa Troso yaitu dengan menjalankan dan menyeimbangkan peran-perannya. Peran tersebut yaitu wanita sebagai istri, ibu, pengurus rumah tangga dan anggota masyarakat. Subjek harus menjalin hubungan kerja sama dengan keluarga dan masyarakat serta dapat membagi waktu antara pekerjaan, keluarga dan masyarakat. Meskipun menjadi pengrajin tenun tetap berperan aktif dalam mengikuti kegiatan-kegiatan PKK.Sebelum berangkat kerja biasanya mereka menyiapkan sarapan, perlengkapan anak sekolah dan saat pulang juga memiliki kewajiban untuk mengurus rumah, menemani anak belajar, berkumpul dengan keluarga.Semua kegiatan yang dilakukan dirumah tersebut, biasanya wanita pengrajin tenun dibantu oleh suami atau orangtua/mertua.Selain itu mereka juga harus mengikuti kegiatan PKK, kegiatan-kegiatan tersebut misalnya keagamaan, kebugaran, arisan, penyuluhan hidup 
sehat, kerja bakti dan sosial. Dengan keterbatasan waktu yang dimiliki, mereka harus pandai membagi waktu sehingga proses interaksi sosial berjalan dengan baik dan lancar.

Faktor pendorong dan penghambat interaksi sosial wanita pengrajin tenundalam kegiatan PKK yaitu pendorong mereka adalah keluarga yang menjadi pembangkit semangat untuk menjadikan kehidupan yang lebih baik serta pengertian dan kerja sama dari keluarga. Sedangkan hambatan terbesar yang dirasakan adalah cara membagi waktu antara pekerjaan, keluarga dan masyarakat. Hambatan yang lain berupa masalah ekonomi dan faktor kelelahan. 


\section{Himmah Wafiroh}

\section{DAFTAR PUSTAKA}

Basrowi.(2005), Pengantar Psikologi, Bogor : Penerbit Ghalia Indonesia, 2005.

Siswanto.(2012)Bimbingan Sosial, Semarang.

Kartono, Kartini. (2006),Psikologi Wanita, Bandung : Mandar Maju.

Gunawan Adisaputro. (2000),Anggaran Perusahaan,Cet. I, Yogyakarta : BPFE

Budi Sutedjo Darma Oetomo. (2006), Perencanaan dan Pembangunan Sistem Informasi, Yogyakarta

Pusat Pembinaan dan Pengembangan Bahasa. (2003), Kamus Besar Bahasa Indonesia, Jakarta : Balai Pustaka

Soekanto ,Soerjono, Sosiologi Suatu Pengantar, Jakarta: Raja Grafindo Persada

Salamun,dkk. (2013)Kerajinan Batik dan Tenun, Yogyakarta: Balai Pelestarian Nilai Budaya Jogjakarta

Departemen Pendidikan RI. (1988)Kamus Besar Bahasa Indonesia, Jakarta : Balai Pustaka

Departemen Pendidikan RI. (1991), Ensiklopedi Nasional Indonesia, Jilid II, Jakarta : PT. Cipta Adi Pustaka, Cet.I

Budiyono, et.al. (2008),Kriya Tekstil: Jilid I, Jakarta : Direktorat Pembinaan Sekolah Menengah Kejuruan

Budi Sutedjo Darma Oetomo. (2006), Perencanaan dan Pembangunan Sistem Informasi, Yogyakarta

Isyanti Dkk, Sistem Pengetahuan Kerajinan Tenun Gedhog Di Tuban Propinsi Jawa Timur, Yogyakarta: Kementrian Kebudayaan dan Pariwisata

http://rubrikbahasa.wordpress.com/2011/06/15/_ pengrajinatauperajin/ 